\title{
POTENTIAL AND PROSPECTUS IN AGRICULTURAL DEVELOPMENT OF LAI CHAU PROVINCE, VIETNAM
}

\author{
Nguyen Thu Thuy \\ Thai Nguyen University of Economics and Business Administration (TUEBA) \\ Vietnam. Group 2, Tan Thinh Ward \\ Tan Thinh, Thai Nguyen City \\ Thai Nguyen Province, Vietnam \\ Email: thuthuytn1211@gmail.com \\ Vietnam \\ Duong Thi Tinh \\ Thai Nguyen University of Economics and Business Administration (TUEBA) \\ Vietnam. Group 2, Tan Thinh Ward \\ Tan Thinh, Thai Nguyen City \\ Thai Nguyen Province, Vietnam \\ Email: tinhvinh@gmail.com \\ Vietnam

\section{Nguyen Quang Hop} \\ Thai Nguyen University of Economics and Business Administration (TUEBA) \\ Vietnam. Group 2, Tan Thinh Ward \\ Tan Thinh, Thai Nguyen City \\ Thai Nguyen Province, Vietnam \\ Email: nguyenquanghop1979@gmail.com \\ Vietnam
}

\section{A R T I C L E I N F O}

Article history: Article

Received: $\quad 5$ February 2021

Revised: $\quad 20$ February 2021

Accepted: $\quad 26$ February 2021

DOI: $\underline{10.47742 / i j b s s r . v 2 n 2 p 1}$

\begin{abstract}
A B S T R A C T
Lai Chau province has many potentialities in agricultural development such as climate, soil, diverse topography, support policies of the Government, locality, long tradition of farming...Period $2016-2020$, the growth rate of the agricultural sector will maintain from $5-6 \%$, the food production is increased, Some dominant crops of the province are being invested for development: tea, medicinal plants, specialty rice... However, the level of deep processing for agricultural products is still low, so the value of goods is not high, the products are mainly consumed in the domestic market, the penetration into supermarkets or export is still limited...Therefore, building a suitable agricultural development orientation will help farmers, businesses, and the Lai Chau province government to have specific solutions in the future to bring high-tech agriculture becomes a key economic direction of the province.
\end{abstract}

Keywords: Agriculture, agricultural products, values, potentials, Lai Chau

\section{Introduction}

Lai Chau is the northwestern province of Vietnam, with an area of 9,068.79 $\mathrm{km} 2$ of which the land used for agricultural production is $84,209.3$ ha. With many diverse topographical features such as valleys, low hills, forests, high mountains, many big rivers...Lai Chau province has many conditions in agricultural development, especially endemic crops. In the past 5 years, many policies in the agricultural development of Lai Chau provinces such as planning of planting areas, supplying seeds, farming techniques, supporting procedures, and capital for agricultural production and processing enterprises. At the same time, with the active participation of the farmer, agricultural enterprises, agriculture's Lai Chau prospered with the increase in productivity and value of agricultural products, some products were present at many supermarkets and reaching the world markets such as tea, Seng $\mathrm{Cu}$ rice, banana, medicinal plants...
During the research process, through the secondary data, the authors have analyzed and evaluated the situation of agricultural development of Lai Chau in the period 2015-2020. The authors found that despite the level the growth rate of agriculture in Lai Chau province has had many achievements but compared with the existing potentials, the development speed is not adequate. Therefore, the article focuses on assessing the existing potential of the agricultural sector, perceptions, and expectations of the people in the province for future agricultural development, thereby suggesting many long-term options to increase the contribution of agriculture in the economic structure of Lai Chau province, improve the quality and value of agricultural products so that farmers' income increases. 
Vol: 2, Issue: 2

February/2021

https://ijbssrnet.com/index.php/ijbssr

DOI: http://dx.doi.org/10.47742/ijbssr.v2n2p1

- Collection of secondary data: including documents, production planning reports, production projects, preliminary and final reports of the People's Committees of province and districts, the Department of Agriculture and Agricultural Development, Department of Statistic in Lai Chau province were announced; Collect documents and data from research projects and related websites...

\section{- Collect primary data:}

+ Subjects, investigation methods, and survey samples: surveyed by random sampling method, surveyed 3 subjects using the prepared form:

(1). Households in 7 districts of Lai Chau province - 700 surveys. (2) The head of the household, the processing establishments, and the agricultural enterprise's Lai Chau province - 150 surveys.

(3). Leaders of specialized divisions and departments at the People's Committees of province and districts in Lai Chau province- 152 surveys.

+ Content of the survey: survey respondents about their prospects, potentials, and expectations for the agricultural development of Lai Chau province in the future

\subsection{Methods of processing and analyzing data}

- General statistical method: Synthesize the data on the contents of production, processing, consumption, environment, and chain of agricultural products in Lai Chau province. The data are used to synthesize and evaluate each agricultural product over the years, according to production development stages.

- Method of comparison: Based on the data collected through the contents to be researched, comparing changes over the years, between reality with the set target, the participation of actor's chain of agricultural products. This contributes to a more comprehensive assessment of the research problem.

- Qualitative analysis method: using the results from the group questionnaire, the authors will analyze the potentials in the agricultural development of Lai Chau province and people's expectations for the level of agricultural growth during the period. From then on, building some plans to bring modern agriculture with many endemic agricultural products to be the main development direction of the locality.

\section{RESULT AND DISCUSSION}

\subsection{Result of agricultural development in Lai Chau province in the period 2016-2020}

Agricultural development in Lai Chau province has been paid attention to and invested in through supportive policies, scale expansion planning, consumption support, and product development. Along with the supports from the central budget such as Decree 210/2013/ND-CP dated December 19, 2013, of the Government on policies to encourage enterprises to invest in agriculture and rural areas, the target program country sustainable poverty reduction (program 30a, 135). Lai Chau province has issued and implemented many policies to support product development such as Policy of converting land to planting rubber trees; Policies for developing high-quality tea areas; Policy for developing cinnamon; Policy for the development of special apple; Policy to support fruit tree development; Support for livestock development...With many supporting capital sources, including central budget capital, the provincial budget has supported agricultural production in the 2016-2020 period, reaching about $2.602,563$ billion VND.

The economic structure of the industry has shifted positively, the growth rate of the agricultural sector has been fairly good, the production value increased on average 5-6\% /year. The cultivated area of food crops has increased every year; People have focused on investing in intensive farming, so crop productivity is increased...Food security is guaranteed and there is a part of agricultural products sold outside the province.

To quickly develop high-quality concentrated tea areas linking the development of raw material areas with the construction of processing factories. Plant structure has changed positively in the direction of promoting advantages, bringing high-value varieties into production, people have paid more attention to investing in intensive farming, increasing productivity and quality. By 2020, the output of some valuable agricultural products of the province includes quality rice area reaching 3,021 hectares, the output will reach 15,105 tons; the tea area is 6,995 hectares with an output of 30,860 tons of fresh tea bud; macadamia trees are 2,704 ha, cinnamon trees reach 6,356 ha.

The cooperative and cooperative economy develops rapidly in both quantity and quality. The role of the cooperative is increasingly strengthened and confirmed in the socio-economic development of the province. Currently, the province has 91 businesses and cooperatives operating in the agricultural sector.

However, the achieved results are not commensurate with the local potential:

- Agricultural production of goods is underdeveloped, small in scale, does not yet have key products, linking the chain of agricultural commodity production is not yet developed, application of agricultural production processes is still very limited.

- Valuable agricultural products and brands have not been formed in the domestic and international markets, and the competitiveness of agricultural products remains low. Agricultural enterprises and cooperatives account for a small proportion, so the level of diversification of agricultural products is low, not improving the value of products.

- Trademark registration, branding, and granting of planting area codes are still few. Currently, there are 08 certified products for trademarks, 01 products (Seng $\mathrm{Cu}$ rice in Than Uyen) with geographical indication, product barcode registration, banana trees in some concentrated banana-growing areas (Phong Tho, Sin Ho) have been given a planting area code.

\subsection{Analysis of potentials in the development of} construction and agricultural product development in Lai Chau province

During the investigation, the authors synthesized and found that there are 3 main potential groups according to the respondents who consider having the main influence on agricultural development of the province, including Natural conditions, Culture traditional agricultural chemistry, Agricultural production development policy, and infrastructure. 
Vol: 2, Issue: 2

February/2021

https://ijbssrnet.com/index.php/ijbssr

DOI: http://dx.doi.org/10.47742/ijbssr.v2n2p1

(CThe Institute of Academic Research and Publication

\subsubsection{Potential from natural conditions}

With the advantage of diverse terrain, rich soil with many different types of land- this is the advantage. to develop agricultural and forestry trees of the province such as afforestation, food crops, vegetables, and especially favorable to the development of many industrial crops with high economic value, such as tea, herbal fruit, macadamia, and temperate fruit trees ...

The favorable climate is very suitable for the development of a variety of crops and animals with high economic value. Lai Chau province has a neutral and temperate climate, not affected by the dry Lao wind like the provinces bordering Laos, without drizzle and drizzle like the Northern Delta, some highland areas over $1,200 \mathrm{~m}$ has a cool year-round climate.

The system of dense rivers and streams belongs to the system of Song $\mathrm{Da}$, Nam Na, and Nam Mu rivers. In parallel with the investment in large hydroelectric projects, especially the system of hydropower reservoirs with large capacity such as hydroelectricity: Son La (capacity 9.6 billion $\mathrm{m} 3$ of water), Lai Chau (capacity 1, 25 billion $\mathrm{m} 3$ of water), Huoi Quang (capacity of 185 million $\mathrm{m} 3$ of water), Ban Chat (capacity of 2.1 billion $\mathrm{m} 3$ of water).

\subsubsection{Potential from traditional agricultural cultures}

Potential in food production: in the province, large sample fields such as Muong Than field, Than Uyen district are formed; Binh Lu, Tam Duong district; Muong Khoa, Tan Uyen district; Noong Heo, Sin Ho district with an area of thousands of hectares, can grow and process high-quality rice with specialty rice varieties such as $\mathrm{San} \mathrm{Cu}$, Khau $\mathrm{Ky}$... with an output of over 10,000 tons/year.

Potential in tea tree development: the whole province of Lai Chau currently has nearly 3,410 ha, mainly concentrated in Tan Uyen, Tam Duong, and Lai Chau city with 3 factories and over 100 production and processing establishments.

Table 1: Evaluation of potentials and prospects for the development of agricultural product chains in Lai Chau province 
Vol: 2, Issue: 2

February/2021

https://ijbssrnet.com/index.php/ijbssr

DOI: http://dx.doi.org/10.47742/ijbssr.v2n2p1

CThe Institute of Academic Research and Publication

http://iarpnet.org/

households with the highest rating reached 85\%/total respondents, followed by the group of managers reaching $80 \% /$ the total number of respondents and the group of enterprises and purchasing households reached $75 \% /$ total number of respondents.

Policy and infrastructure for agricultural production development are also chosen by the majority of respondents as the potential to help develop the value chain with the following results: $80 \%$ for households, $95 \%$ for households group of enterprises, purchasing households, $100 \%$ of groups of managers. In this context, the respondents gave 5 main groups, including Policies to support agricultural development; Traffic system; Hydropower system; Labor resources; Diversity in the forms of organization of agricultural production, processing, and consumption with a level of the consent of $70 \%$ or more of respondents.

Table 2: Outlook for agricultural product consumption market in Lai Chau province

With the potentials to build and develop the value chain of agricultural products of Lai Chau province with many opportunities to promote in the future, when asked about the prospects of agricultural product consumption in the province, the target groups all said they believe in the possibility of developing and expanding market for Lai Chau agricultural products in the future. Table 2 , over $80 \%$ of the respondents realize that in the future the main potential customer group will be customers outside the province. Thanks to the incentives in the policies to attract businesses, promote product promotion, and invest in infrastructure, Lai Chau's agricultural products will be known and favored by many consumers across the country, especially the typical local agricultural products. At the same time, businesses and collectors also boldly focused on exporting goods to some markets such as China, Taiwan, Russia... with key products such as tea, medicinal plants, rice...

Unit: \%

\begin{tabular}{|l|c|c|c|}
\hline \multicolumn{1}{|c|}{ Contents } & Household & Businesses, households purchasing & Managers \\
\hline 1. Potential customers & & & 40 \\
\hline - In the province & 70 & 100 & 90 \\
\hline - Out of the province & 80 & & 100 \\
\hline 2. Potential market & & 100 & 40 \\
\hline - Domestic & 100 & 50 & \\
\hline - Export & 25 & & $($ Source Compiled fiom surve questionnaie) \\
\hline
\end{tabular}

(Source: Compiled from survey questionnaire)

\subsection{Orientation in agricultural development in the coming time}

In the coming time, $100 \%$ of respondents feel that it is necessary to expand agricultural production in different ways such as the increase in output, production equipment, labor ... At the same time, realize that Increasing the level of linkages between stakeholders will promote agricultural production, increase the value of agricultural products. The highest proportion of respondents choosing the plan to develop agricultural enterprises, because businesses can manage product quality, process, and consume most actively, thereby bringing efficiency. the biggest fruit in sustainable agricultural development. Next is a cooperative model with the rate of choice between 15-30\% depending on the respondents. Combining the above economic sectors is the cooperation linkage in each stage of the value chain, which is selected in the range of $10-15 \%$. The remaining $20 \%$ is for other members including cooperative group; farm; family.

Table 3: Orientation of agricultural production association in Lai Chau province

\begin{tabular}{|l|c|c|c|}
\hline \multicolumn{1}{|c|}{ Contents } & Household & Businesses, households purchasing & Managers \\
\hline $\begin{array}{l}\text { 1. Increase the level of production } \\
\text { integration along the value chain }\end{array}$ & 40 & 100 & 100 \\
\hline 2. Expand production scale & 100 & 100 & 100 \\
\hline - Increase collection output & 20 & 25 & 23 \\
\hline - Increase investment in equipment & 35 & 45 & 40 \\
\hline - Increase working capital investment & 30 & 25 & 27 \\
\hline - Increase labor scale & 15 & 5 & 10 \\
\hline $\begin{array}{l}\text { 3. The main economic component in } \\
\text { enhancing the value of agricultural products }\end{array}$ & & & \\
\hline
\end{tabular}


CThe Institute of Academic Research and Publication

Vol: 2, Issue: 2

February/2021

https://ijbssrnet.com/index.php/ijbssr

DOI: http://dx.doi.org/10.47742/ijbssr.v2n2p1

\section{- Enterprise}

\begin{tabular}{|l|c|c|c|} 
- Enterprise & 35 & 65 & 50 \\
\hline - Cooperative & 30 & 15 & 20 \\
\hline - Cooperation group & 7 & 3 & 5 \\
\hline - Cooperation group & 8 & 5 & 10 \\
\hline - Farm & 5 & 2 & 5 \\
\hline - Family & 15 & 10 & 10 \\
\hline $\begin{array}{l}\text { - Combining the above economic } \\
\text { components }\end{array}$ & 35 & 65 & 50 \\
\hline
\end{tabular}

(Source: Compiled from survey questionnaire)

From there, the authors suggest some options for the development of agricultural products in Lai Chau province in the coming time as follows:

\section{- Diversify agricultural products}

- Development of key products: Towards the in-depth development of national key products, provincial products, and local products.

- Development of agriculture in potential areas: It is necessary to plan production areas with favorable conditions and the ability to plant typical crops to form large-scale commodities, associated with the regional strengths in high-quality agriculture, clean technology, and high added value...

- Developing commodity value chains

The first, Developing agricultural products towards the direction of high technology application; sustainable development associates production with processing.

Secondly, to develop agricultural products based on exploiting the advantages of each agro-ecological region. To build and develop brands of local "specialties" or natural advantages to develop regional brands (such as Cong $\mathrm{Cu}$ rice, $\mathrm{Co}$ Giang glutinous rice, Da river fish, Sin Ho medicinal herbs, tea...).

Thirdly, the planning for the development of agricultural products of the province goes hand in hand with the investment and restructuring of crops and animals; encourage land accumulation to form large sample fields.

Fourthly, to encourage all economic sectors and investors inside and outside the province to invest in developing agricultural products in key regions. To focus on production areas and stabilize the product supply source as a premise for the processing industry.

Last, Develop diversified forms of agricultural organization and agricultural product transactions. Renovating the organizational model and management modes of state agricultural enterprises; consolidating the development of cooperatives and farmers' cooperative economic groups; development of large-scale commodity farms; encourage the development of value chain tissue with the key role of processing and consuming enterprises.

\section{CONCLUSION}

With a province facing many difficulties like Lai Chau, agricultural development is still the main direction in the province's economic growth in the coming time. However, development should focus not only on increasing output but also on increasing the value of crops, investing in deep processing of agricultural products ... thus, will help agriculture develop sustainably. To do that, the province, districts, businesses, and farmers need to focus on several issues as follows:

\section{Improve the quality of agricultural products:}

Improving the quality of plant and animal breeds: Coordinating with other units to research and transfer new, disease-free, high-yield, and high-quality crop and animal varieties.

Organize training courses and increase the application of technical advances to improve productivity and quality of agricultural products: organize training for farmers on modern agricultural production processes; to intensify the application of scientific and technological advances to production to improve the quality of agricultural products.

Innovating technology, improving processing capacity: using high technology in product preservation and packaging's such as vacuum machines, incubators, packaging machines to improve product quality; supporting businesses and cooperatives to invest in building, renovating, and upgrading technology lines; to invest in modern equipment and equipment for agricultural production and processing.

Branding, developing the product consumption market

Branding, trademarks for products: building, managing and using "geographical indications" for specialty products originating from Lai Chau; building a set of brand formats: logo, label, sologan, flyer, the website of agricultural products; design, packaging modern, safe, suitable for consumer tastes and friendly with the environment.

Promoting trade promotion activities, participating in and expanding markets: expanding consumption markets through many different forms of sales; connecting product markets; promote product brand...

Complete the infrastructure system for the development of value chains of agricultural products

Improve the quality of planning construction and effectively implement sectoral and sectoral planning's.

Innovating the content and methods of investment in agriculture and rural areas in the direction of increasing the rate of investment capital for the agricultural product processing 
Vol: 2, Issue: 2

February/2021

https://ijbssrnet.com/index.php/ijbssr

DOI: http://dx.doi.org/10.47742/ijbssr.v2n2p1

http://iarpnet.org/

industry and rural services, building and upgrading rural infrastructure, hunger eradication, poverty reduction.

\section{REFERENCES}

Decision No. 1447 dated 5/11/2019 of the People's Committee of Lai Chau Province on promulgating the list of key agricultural products in Lai Chau province.

Decision No. 1446 dated November 5, 2019 promulgating important commodity sectors and products to encourage and prioritize support to link with production and product consumption in Lai Chau province

Khai, V.T, 2012. Promoting consumption of agricultural products through consumption contracts in Thua Thien Hue province, Scientific Journal of Hue University.

Khoozani, A.A., Birch, J., \& Bekhit, A.E.D.A, 2019. Production, application and health effects of banana pulp and peel flour in the food industry, Journal of Food Science and Technology, Vol.56: 48-559.

Lai Chau Provincial Party Committee, Resolution of the 13th Lai Chau Provincial Party Congress, term 2015 - 2020

Nga, D.T, 2016. Linking farmers and businesses in coffee production and consumption in the Central Highlands, Vietnam Agricultural Science Journal.

Phuong, D.T.T, 2016. Analysis, construction and development of the tea industry value chain in Yen Bai province, Yen Bai provincelevel scientific research project.

Phuoc, V.H, 2010. Strengthening the linkage of four households in production and consumption of agricultural products in the province, Academy of Social Science.

Report on the results of the implementation of agricultural and forestry development tasks in 2019, plans and plans for 2020, Lai Chau.

Statistical Publishing House of Lai Chau Province priod 2016 - 2020. 